\title{
Colletotrichum coccodes, patógeno de solanáceas no Brasil
}

\author{
Maria Helena D. Costa, Ludwig H. Pfenning \& Edson A. Pozza \\ Universidade Federal de Lavras, Departamento de Fitopatologia, Cx. Postal 3037, CEP 37200-000, \\ Lavras, MG, e-mail: ludwig@ufla.br
}

(Aceito para publicação em 07/03/2006)

Autor para correspondência: Ludwig H. Pfenning

\begin{abstract}
Occurrence of Colletotrichum coccodes, a pathogen of Solanaceae in Brazil.

Colletotrichum coccodes is a common pathogen causing anthracnoses and black-dot in crops like tomato, pepper and potato. A morphological characterization and illustrations of the pathogen are presented for the first time in Brazil.
\end{abstract}

Colletotrichum coccodes (Wallr.) S. Hughes é o agente etiológico de doenças como "antracnose" e "black-dot" em solanáceas, causando prejuízos expressivos em diversas áreas do mundo (Andrivon et al., Plant Pathology 47:440. 1998). O fungo possui vários sinônimos o que dificulta a análise de sua ocorrência e distribuição geográfica, inclusive a adoção de medidas quarentenárias [Bailey \& Jeger (Eds.) Colletotrichum, CAB International, 1992. p.225]. Dentre os sinônimos destaca-se com maior uso Colletotrichum atramentarium (Berk. \& Broome) Taubenh. Embora o teleomorfo da espécie não seja conhecido, o gênero Colletotrichum é classificado na ordem Phyllachorales. O patógeno pode ser encontrado com freqüência causando doenças em diferentes espécies e variedades de solanáceas, mas é pouco conhecido no Brasil. Para o território brasileiro, existem somente relatos escassos, sendo estes de Viégas (1940; Índice de Fungos da América do Sul) e Wellman (1972; Dictionary of Plant Diseases of Tropical America), transcritos nos Catálogos de Reifschneider (1983; Índice de Doenças de Hortaliças) e Mendes (1997; Fungos em Plantas do Brasil). Em frutos de tomate e pimentão, os sintomas são conhecidos como antracnose afetando o caule, raízes, frutos verdes e maduros, onde se forma uma lesão circular, deprimida, com escurecimento central e produção abundante de acérvulos, setas e microesclerócios (Figura 1A-C) (Andrivon, Plant Pathology 47:440. 1998; Dillard, Phytopathology 79:1063. 1989). Os danos causados por este patógeno resultam tanto na redução direta da qualidade e quantidade do fruto, como no aumento dos custos de produção e de pós-colheita. No batateiro observa-se a colonização de todos os órgãos subterrâneos. Na raiz e no caule aparece podridão, na superfície dos tubérculos lesões prateadas com intensa produção de microesclerócios pretos. Nas folhas, o sintomaé amarelecimentoe, eventualmente, morte prematura da planta. A qualidade de tubérculos, tanto para consumo como para semente, é reduzida. A batata semente infectada pode representar ainda importante fonte de inoculo, inclusive para plantios futuros de solanáceas. $\mathrm{O}$ fungo cresce em meio MA $2 \%$ e BDA com uma taxa de crescimento média de $1 \mathrm{~cm}$ por dia e esporula com facilidade em V8. Há uma intensa produção de setas septadas com suas extremidades agudas, de comprimento de 80 a $350 \mu \mathrm{m}$. Os conídios são fusiformes com as extremidades obtusas, hialinos, asseptados, medem 16-24 x 2.5-4.5 $\mu \mathrm{m}$ e formam uma massa de aparência amarela a rosada (Figura 1D-E). Tanto em tecido vegetal, como em meio de cultura o fungo produz esclerócios em abundância, de 100-500 $\mu \mathrm{m}$ de diâmetro (Figura 1F). As espécies C. gloeosporioides (Penz.) Penz. \& Sacc. e C. acutatum J.H Simmons também ocorrem em solanáceas com sintomatologia inicial parecida, entretanto tais espécies têm micromorfologia diferente, além de não produzirem os microesclerócios pretos, característicos da espécie $C$. coccodes.

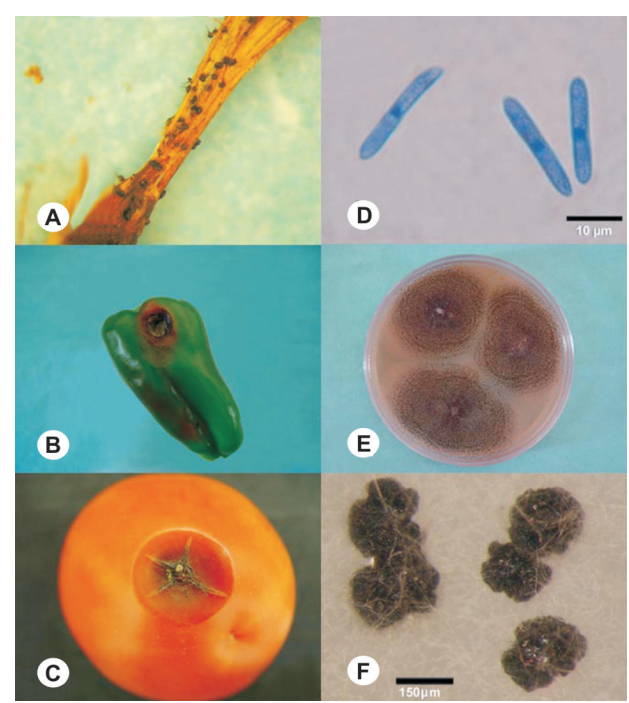

FIG. 1 - Colletotrichum coccodes. A. Podridão em raiz de batata; B e C. Antracnose em frutos de pimentão e tomate; D. Conídios; E. Cultura pura em meio V8 com produção abundante de microesclerócios; F. Esclerócios produzidos em meio MA. 